\title{
PORT RISK ASSESSMENT IN CONTAINER TERMINALS: THE CASE OF TUNISIA
}

\author{
SMARI SIHEM \& NOUMEN ROBERT \\ Laboratory Cepn-Cnrs, Paris Sorbonne University, France
}

\begin{abstract}
The maritime sector is a complex, vulnerable transport network characterized by the disintegration and heterogeneity of its actors. The reticular structure of this network exposes the movement of containers to several risks. A maritime transport chain includes several actors working in a complex environment, in order to reduce the scope of our research. In this context, based on the existing literature on maritime risks in general, and port risks (within the port perimeter) in particular, we have compiled a comprehensive list of conceivable risks. We compared it with the risks that were identified in the TUNISIAN context. Our risk identification technique is a mixture of methodology (qualitative interviews with practitioners, existing literature and port data). In our study, the approach used to assess and analyse risks is the port risk assessment, which is a multi-step process (system identification, risk identification, risk assessment, risk control options and decision-making)

This paper contributes to the current risk management literature by confirming certain risks (in the literature) and offering new ones that have been specific to the Tunisian context (lack of a strategic role for the state with a low level of transparency). The risk assessment with an in-depth diagnosis aims to develop recommendations for optimized management while improving resilience, and it will serve as a remarkable efficiency tool that facilitates decision-making and the achievement of objectives.

Keywords: Risk assessment, port, container terminal, Tunisia.
\end{abstract}

\section{INTRODUCTION}

Maritime transport plays a crucial role in the global economy and trade relations. The craze for this mode of transport is due to the relocation of production units away from consumption units and the large capacity to transport large quantities at affordable prices. This maritime transport chain is characterized by increased uncertainty from the point of view of stakeholders, which appears to be the main challenges of risk management. The ability to identify risks has weakened; this difficult situation is particularly marked in multimodal supply chains, where the risks and location of actors are high [1].

A better understanding of risk management in a complex multimodal context is therefore essential in maritime logistics.

Indeed, the concept of risk management remains an important topic that has attracted the attention of researchers and professionals in all fields. Indeed, risk management is the decision-making process by which actions are taken after an assessment.

\section{PORT RISK MANAGEMENT}

We will present the definition of some major concepts that are related to port risk management.

\subsection{Risks}

Aven [2] has historically analysed the concept of risk and classified it into certain categories. Category D1 defines risk as the expected value of the probability of an event occurring and the utility of events. Category D2 defines risk as the probability of an adverse event. In D3, 
risk is defined as an objective uncertainty. Category D4 represents risk as equal to the value of the uncertainty. In category D5, risk is defined as the possibility of loss. According to D6, risk is the combination of the probability of an event occurring and severity (consequences). Category D7 considers risk as an event or consequence. D8 defines risk as a combination of events, consequences and their uncertainty. And finally, category D9 defines risk as an effect of uncertainty on objectives.

Table 1 summarizes the various categories.

\subsection{Risk management}

Métayer and Hirsh [3] define the risk management as a term used to describe acts that aim to identify risks, to characterize them and to minimize their effects and consequences. Management is a broader term that encompasses management actions related to risk management. Supply chain risk management is defined as 'the identification of potential sources of risk and implementation of appropriate strategies through a co-ordinated approach among supply chain members to reduce supply chain vulnerability' [4].

\subsection{Maritime risk management}

Yang [5] presented the definition of the maritime supply chain risk management as 'the process of making and carrying out decisions that will minimize the adverse effects of accidental losses, and is based on risk assessment methods involving co-operation and communication between all members involved in maritime supply chain activities'.

The risk management culture is based on prevention, anticipating risks instead of waiting for accidents. In this context, Pallis [6] points out that the shipping industry is in the process of moving from a reactive to a preventive approach to safety through what is known as formal safety assessment (FSA).

Table 1: Risk categories [2].

\begin{tabular}{ll}
\hline Category & Risk \\
\cline { 2 - 2 } & Definition \\
\hline D1 & Risk = expected value \\
D2 & Risk = probability of an adverse event \\
D3 & Risk = objective uncertainty \\
D4 & Risk = uncertainty \\
D5 & Risk = possibility of loss \\
D6 & Risk = the combination of the probability of an event occurring and the \\
& severity \\
D7 & Risk $=$ an event or consequence \\
D8 & Risk $=$ the combination of events, consequences and their uncertainty \\
D9 & Risk = an effect of uncertainty on objectives \\
\hline
\end{tabular}




\section{LITERATURE REVIEW DEALING WITH RISKS IN PORT CONTAINER TERMINALS}

The question that arises is: What risks have been taken into account in most of the studies that have addressed maritime risks?

The first classification is made by Chang et al. [7] who have classified the risks into three categories (Table 2):

- Risk associated with physical flow

- Risk associated with payment flow

- Risk associated with information flow

A second classification was made by Yang [5], and Table 3 summarizes this distinction.

Table 2: Risk categories in container shipping operations [7].

\begin{tabular}{lll}
\hline Context & Category & Risks \\
\hline Container & Physical risks [7] & Port strike \\
shipping & & Port congestion \\
operations [7] & Port productivity being below expectations \\
& Unstable weather \\
& Inappropriate empty container transportation \\
& Lack of flexibility of fleet size \\
& Damage to container \\
& Cargo being stolen from unsealed container \\
& Damage caused by transporting dangerous goods \\
& Terrorist attack \\
& Change of currency exchange rate during payment \\
& process \\
& Payment delay from partners or shippers \\
& Unrealized contract with partners \\
& Shippers going into bankruptcy \\
& Shippers breaking the contract or reducing the \\
& container volume \\
& Having partners with bad credit \\
& The increase in the time required to transmit \\
& information \\
& Partners do not transmit essential information on \\
& time \\
& Shipping company not transmitting essential \\
& information on time \\
& Lack of information security during the \\
& information flow \\
& Unsuitable human operation on application \\
& software \\
& Lack of information \\
\hline &
\end{tabular}


Table 3: Risk categories in maritime supply chain [5].

\begin{tabular}{lll}
\hline Context & Category & Risks \\
\hline Maritime supply & Operational risk [5] & Longer lead time of data entering \\
chain [5] & & Various transmission systems \\
& Lower elasticity of manifest revision \\
& Increasing stock number \\
& Increasing security barriers \\
& Double inspection \\
& Container inspection charge \\
& Longer cargo handing time \\
& Additional document charge \\
& Financial risk [5] [5] & Disclosure of business information \\
& Finance loss \\
& Reputation loss \\
\hline
\end{tabular}

Pallis [6] presented a review of different approaches to quantify the risk in container terminal. In risk assessment, the most important step is the risk identification. In this step, he uses the existing literature and interviews with practitioners to present all the risks existing in a container terminal.

Table 4 presents all the risks that have been identified.

The current literature offers many options of classification, for example, Juttner et al [8] specify three risk groups: internal risks, supply chain risks and external risks.

Manuj and Mentzer [9] present another classification: supply risks, operational risks, demand risks, security risks, macro risks, policy risks, competitive risks and resource risks

Vilko et al. [10], identified 103 risks by conducting a qualitative study, and these risks have been classified into two categories (exogenous and endogenous). The results show that the exogenous risks (fuel price, traffic jam, monopoly, electricity blackout, old shipping lane, storms, spying and espionage) had a greater impact in terms of time and costs, whereas the endogenous risks (ship collisions, not enough personnel, irresponsibility, drunken drivers, document interpretation problems, shipping company's monopoly and social problems were responsible for more of the quality damage.

\section{RESEACH METHODOLOGY}

As previously announced, our study context is the Tunisian context (the port of Radès).

Tunisia has a coastline of $1,300 \mathrm{~km}$ in the north of the African continent with an advantageous geographical location in the middle of the Mediterranean basin. The Tunisian port chain is composed of seven ports that are open to international trade, which is characterized by an exceptional location (a European market and an African continent). Tunisia is the hub of the Mediterranean basin because of its geographical location. There are seven Tunisian seaports (which provide $98 \%$ of Tunisian trade with the world).

\subsection{Interview}

Interviews were conducted to confirm the risks identified in previous studies and to explore risks that are related to the Tunisian context. We tried to cover the entire supply chain in 
Table 4: Risk categories in port container terminal [6].

\begin{tabular}{|c|c|c|}
\hline Context & Category & Risks \\
\hline \multirow[t]{5}{*}{$\begin{array}{l}\text { The port/ } \\
\text { container } \\
\text { terminal [6] }\end{array}$} & Human risks [6] & $\begin{array}{l}\text { Ship collisions } \\
\text { Grounding } \\
\text { Sinking } \\
\text { Navigation error } \\
\text { Pilotage error } \\
\text { Poor maintenance } \\
\text { Falling of a crane } \\
\text { Falling of a container } \\
\text { Error in Cargo handling and storage }\end{array}$ \\
\hline & Machinery risks [6] & $\begin{array}{l}\text { Damage to equipment } \\
\text { Fire/explosion } \\
\text { Machinery failure } \\
\text { System failure }\end{array}$ \\
\hline & Environment risks [6] & $\begin{array}{l}\text { Ships emissions } \\
\text { Dredging } \\
\text { Oil spills } \\
\text { Chemical contaminants } \\
\text { Ballast waters } \\
\text { Ship breaking } \\
\text { Air toxics } \\
\text { Noise pollution } \\
\text { Alien species }\end{array}$ \\
\hline & Security risks [6] & $\begin{array}{l}\text { War/political instability } \\
\text { Terrorist } \\
\text { Theft } \\
\text { Smuggling } \\
\text { Illegal trade } \\
\text { Vandalism } \\
\text { Illegal immigration } \\
\text { blockade }\end{array}$ \\
\hline & Natural risks [6] & $\begin{array}{l}\text { Ship emissions } \\
\text { Earthquakes } \\
\text { Volcanic eruptions } \\
\text { Hurricane } \\
\text { Strong winds } \\
\text { Heavy swell and sea floods } \\
\text { High temperature during working hours } \\
\text { Heavy rain }\end{array}$ \\
\hline
\end{tabular}


the terminal, interviewing two to three people from each department, taking into account a professional experience that exceeds 7 years. Seventeen managers were interviewed - ten senior operation managers, three logistics personnel, three department managers and one vice president.

We explored the risks in the port terminal in four steps: in the first stage, the risks were identified through in-depth interviews that began in December 2016 to identify interesting development paths. At the beginning of each interview, the person was promised anonymity to put him/her at ease.

These interviews also allowed us to validate the risk factors that have been identified in the literature and to explore other risks that have not been invoked in previous studies in other contexts (Taiwan and Greece).

As announced at the beginning, our risk identification technique is a mixture of methodology (port data, existing literature and interviews with practitioners). We tried to exploit the content of the statistics that were provided by the port during our first discovery visit (December 2016). The risk management culture is based on prevention, anticipating risks instead of waiting for accidents. In this context, Pallis [6] points out that the shipping industry is in the process of moving from a reactive to a preventive approach to safety through what is known as FSA. This concept was introduced by the IMO = International Maritime Organization.

Pallis [6] proposed in 2017 a port risk assessment process called 'PRA' (port risk assessment). The PRA is a process that was inspired by the ASF, keeping the same steps of the process but modifying the content. This change focused on content, adopting it in the context of ports.

The process consists of six steps as follows:

- System identification (Port)

- Risk identification (what go wrong?)

- Risk assessment (investigation of important risks)

- Risk control options (measures to mitigate risks)

- Cost/benefit assessment (cost/benefit of measures)

- Decision-making (recommendation)

In our study, we applied the PRA except for step number 5 (cost/benefit assessment) because we do not have enough data.

\section{RESULTS AND DISCUSSION}

The risks that are taken into account in the official documents of the port administration are very general. This risk identification does not take into account the current situation of the port and the economic situation of the country especially after the revolution (the so-called Arab spring).

According to the official port statistics, the risks can be summarized in the following points:

- Import transfer

- GT and other equipment down

- Export transfer

- Lack of staff

- Waiting GT

- Lack of transfer equipment 
- Crane movement

- Diesel fuel supply

- Others

In Tunisian context, there is a huge difference between the risks mentioned below and the reality of the ports, we noticed this by questioning the managers and maritime actors.

- centralization in decision-making with a disengagement from control responsibilities

- Insufficient studies and clear and quantifiable strategies that have treated the Tunisian context, which remains like a black box that we only hear about when high-risk events appear

- Absence of a strategic state

- The long residence time of the goods

- High waiting time for ship handling, which leads to additional costs

- Corruption

- Insufficient safety features

- Long customs procedures

- The low level of automation (major problem in the location of containers ready for delivery)

The risk identification is the most important step in this process; according Trbojevic and Carr [11], the aim of risk identification is to produce a comprehensive list of risks.

In Tunisian context, the majority of risks that have been taken in consideration are only technical risks that are directly related to the equipment without any indication of other risk categories (e.g. human risks).

Some of the investigated practitioners had a problem in forming a holistic view and his opinions remain closed and closely linked to his function.

The following table summarizes the risks that were recorded with the recommendations from interviews.

According to the stakeholders' points of view, the risks identified can be classified into two categories: internal risks and external risks.

\begin{tabular}{|c|c|c|}
\hline & Risks & Some recommendations \\
\hline $\begin{array}{l}\text { Internal } \\
\text { risks }\end{array}$ & $\begin{array}{l}\text { Damage to equipment } \\
\text { System failure } \\
\text { Import transfer } \\
\text { Crane movement } \\
\text { Lack of transfer equipment } \\
\text { Container inspection charge } \\
\text { Longer cargo handing time } \\
\text { Additional document charge } \\
\text { Port strike } \\
\text { Port congestion } \\
\text { Port productivity being below } \\
\text { expectations. } \\
\text { Low added value of port activities } \\
\text { Corruption } \\
\text { Low skill level of senior managers }\end{array}$ & $\begin{array}{l}\text { Creation of a department dedicated to } \\
\text { port development } \\
\text { Implementation of a land security policy } \\
\text { Automation of input-output procedures } \\
\text { Setting up high-level training for } \\
\text { managers } \\
\text { Modernize the current system in order to } \\
\text { streamline procedures } \\
\text { Staff education and training }\end{array}$ \\
\hline
\end{tabular}




\begin{tabular}{|c|c|c|}
\hline External risks & $\begin{array}{l}\text { Heavy decision-making and } \\
\text { management mechanisms at } \\
\text { port authority level } \\
\text { Lack of port strategy } \\
\text { Discrepancy between the } \\
\text { required yields and those } \\
\text { observed in the field } \\
\text { Insufficient port investments } \\
\text { Political instability } \\
\text { Terrorist } \\
\text { Theft } \\
\text { Vandalism }\end{array}$ & $\begin{array}{l}\text { The state must assume its strategic } \\
\text { role and no longer get involved in } \\
\text { management affairs } \\
\text { Strengthen security and control } \\
\text { mechanisms }\end{array}$ \\
\hline
\end{tabular}

\section{CONCLUSION}

The study aims to identify and analyse the risks in container terminals. The approach used to assess and analyse risks is the PRA, which is a multi-step process (system identification, risk identification, risk assessment, risk control options and decision-making). The finding of the paper can be summarized as follows.

First, as announced in the beginning, our risk identification technique is a mixture of methodologies which include port data, existing literature and interviews with practitioners, and the risks that are taken into account in the official documents of the port administration are very general. The majority of the risks that have been taken into consideration are only technical risks that are directly related to the equipment.

Second, in interviews with port stakeholders, a significant difference between the risks in official documents and the catastrophic situation of the port was noted, highlighting other more relevant risks.

Third, the high waiting time for ship handling, which leads to additional costs, and corruption are the major risks associated with a high degree of seriousness that require risk mitigation strategies.

Finally, the qualitative nature of our study causes some limitations. The risk assessment is based on the personal experiences of the interviewees which represent the subjective views of the experts in question.

To overcome this limitation, further qualitative and quantitative studies are needed to deepen our analyses and generalize our results.

\section{ACKNOWLEDGEMENTS}

My warm thanks to the staff of the port of Radès (Tunisia) who facilitated my access to information without forgetting the research laboratory CEPN-CNRS (Paris-France).

\section{REFERENCES}

[1] Vilko, J., Ritala, P. \& Hallikas J., Risk management abilities in multimodal maritime supply chains: Visibility and control perspectives. Accident Analysis \& Prevention, 2016.

[2] Aven, T., Foundational issues in risk assessment and risk management. Risk Analysis, pp 1647-1656, 2012.

[3] Métayer, H \& Yves, L., Premiers pas dans le management des risques, Afnor, 2017. 
[4] Christopher, M., Peck, H. \& Rutherford, C., Understanding supply chain risk: A selfassessment workbook, Cranfield University, School of Management, Department for Transport, 2003.

[5] Yang, C., Risk management of Taiwan's maritime supply chain security. Safety Science, pp 382-393, 2011.

[6] Pallis, P., Port risk management in container terminals. Transportation research procedia, pp 4411-4421, 2017.

[7] Chang, C, Xu, J. \& Song, D., An analysis of safety and security risks in container shipping operations: A case study of Taiwan. Safety Science, pp 168-178, 2014.

[8] Juttner, U., Peck, H. \& Christopher, M., Supply chain risk management. International Journal of Logistics Research and Applications, 197-210, 2003.

[9] Manuj, I. \& Mentzer, J., Global supply chain risk management. Journal of Business Logistics, 135-155, 2008.

[10] Vilko, J., Ritala, P. \& Hallikas, J., Risk management ability in multimodal maritime supply chains: visibility and control perspectives. Journal of Accident Analysis and Prevention, G model, AAP 4341-4354.

[11] Trbojevic, V.M. \& Carr, B.J., Risk based methodology for safety improvements in ports. Journal of Hazardous Materials, 71, 467-480, 2000. 